\title{
Impact of Venture Capital Investment Syndication on Enterprise Lifecycle and Success
}

\author{
Asif Siddiqui ${ }^{1}$, Dora Marinova ${ }^{1} \&$ Amzad Hossain ${ }^{1}$ \\ ${ }^{1}$ Curtin University, Australia \\ Correspondence: Dora Marinova, Curtin University, Australia. E-mail: D.Marinova@curtin.edu.au
}

Received: February 5, 2016

Accepted: March 21, 2016

Online Published: April 25, 2016

doi:10.5539/ijef.v8n5p75

URL: http://dx.doi.org/10.5539/ijef.v8n5p75

\begin{abstract}
The article investigates the impact of venture capital investment and investment syndication on enterprise lifecycle and success using the exit history of venture capital backed companies in Australia. It is observed that the venture capital backed companies tend to outperform those which are not while companies receiving syndicated venture capital investment tend to outperform the other venture capital backed companies. Based on the classic venture capital investment theory, we argue that venture capitalists essentially engage in superior venture selection through pre-investment screening and contribute to entrepreneurial development through post-investment monitoring and value creation. We then empirically investigate the lifecycle of the Australian venture capital backed companies from company formation to first venture capital financing round to exit. Survival duration of the ventures, investment growth and exit status are specifically analysed to capture the lifecycle. The findings show that the survival duration prior and post venture capital investment, venture capital investment growth in successive rounds and investment syndication increase the probably of success for the ventures.
\end{abstract}

Keywords: venture capital, investment syndication, enterprise lifecycle, survival, sustainability

\section{Introduction}

\subsection{Venture Capital Investment}

Venture capital (VC) is usually invested in the high-risk early stage technology enterprises; these companies often introduce new products and processes and their entrepreneur managers can be relatively inexperienced (Bygrave \& Timmons, 1992; Tyebjee \& Bruno, 1984a). Despite the initial investment risk associated with such enterprises, $\mathrm{VC}$ investment has earned significant prominence in the last few decades. Venture capital fund managers not only created most influential corporations such as Skype, YouTube and Facebook but also generated attractive returns for the investors (Gompers \& Lerner, 2001; Cochrane, 2005). The success of the VC-backed enterprises obviously makes this type of investment attractive for investors as well as interesting from an academic point of view. It is also not surprising that the VC industry has developed a number of practices over time that best suit the environment in which it operates in order to maximise the risk-adjusted return on investments. Such practices are represented in the VC investment process. They include financing in stages, using convertible securities, considering investment syndication and monitoring the portfolio through active management (Berglöf, 1994; Gompers, 1995; Hellmann, 1998; Repullo \& Suarez, 2004). It is however not simple to determine the influence of each element or practice of the VC investment process on the ventures' success. The combination of all practices and strategies arguably influences the ventures' performance.

\subsection{Syndication}

A common investment practice in the VC industry is investment syndication. This has attracted significant research attention from different disciplines, including issues such as what are the drivers for syndication and the influence of syndication on the ventures' success. It has been argued that syndication improves venture selection through information aggregation and that syndicating VC firms enhances performance by combining resources and expertise (Lerner, 1994; Brander, Amit, \& Antweiler, 2002; Hopp \& Rieder, 2011). Syndication also connects VC managers with other industry players, such as financial advisors, bankers, underwriters, accountants and lawyers (Bygrave, 1987; Hochberg, Lyungqvist, \& Lu, 2007). It appears that the syndication network offers benefits for both, venture capitalists and entrepreneurs. This not only facilitates the flow of information and 
resources across the industry, but also creates a social platform for the industry practitioners. Such platform can help in standardising good business practices and thereby can reshape and strengthen the industry culture.

However, VC firms do not seek syndicate partners for all venture investments as syndication may complicate the management process (Wright \& Lockett, 2003). Agency problems resulting from syndication are higher initial public offerings (IPO), under-pricing and lower aftermarket performance (Chahine, Arthurs, Filatotchev, \& Hoskisson, 2012). Thus, a significant number of VC firms do not initiate syndication and consequently the portfolio companies do not receive syndicated investments.

Nonetheless, most studies relate syndication with venture success. Certainly, the selection of a suitable syndication partner could minimise any potential agency problems; hence the issue of syndication partner selection has received significant attention (Tykvová, 2007; Hochberg et al., 2007; Hopp \& Lukas, 2014; Gu \& $\mathrm{Lu}, 2014)$. The literature however does not necessarily explain what factors influence the success of ventures receiving investments from a single or syndicate of VC firms. Thus, it is interesting to study the lifecycle of successful enterprises and analyse some characteristics shared by syndicated and standalone ventures to understand the key factors that contribute to success.

This approach is significantly different from evaluating syndication with the aim to increase the probability of a venture's success as often explored in the literature. The analytical insight and empirical investigation in this investigation focus on the lifecycle of successful enterprises which have attracted VC investment and pose the question as to what role the use of syndication has played. This study enriches the VC literature by adding an aspect that has not been explored before. It also provides practical insights for the industry participants through emplacing on the VC firms' expertise and experience in screening quality ventures and adding value which is reflected throughout the lifecycle of the venture from survival to success.

\subsection{Venture Capital as an Investment Model}

In analysing the $\mathrm{VC}$ investment decision of an individual or syndicate of $\mathrm{VC}$ firms, we expect that the decision process in relation to investee companies would follow broadly the same steps as outlined in the classic VC investment theory (Tyebjee \& Bruno, 1984a; Ruhnka \& Yong, 1987; Fried \& Hisrich, 1994) which explains venture capital as an investment model. It states that irrespective as to whether the VC firms are investing alone or as a syndicate, they go through two broad phases, namely pre-investment selection and post-investment value creation process. The syndicates however may have the advantage of gathering more information during the venture selection process as well as combining more resources and expertise during the post-investment value creation process. In both cases, the selection of a quality venture and strong post-investment value creation are the key to the ventures' success.

\subsection{The Study}

For the analysis to follow we develop indicators signalling the ventures' quality and value enhancement in order to analyse their survival and duration. Then we relate the indicator variables to the ventures' success and analyse the contribution syndication makes. Australian data are used in the empirical investigation and the results evidently depict certain characteristics of the Australian VC industry. We also suggest that the strength of the VC investment model can contribute for developing ventures related to innovation in clean technologies and achievement of other social goods that are much needed to respond to the emerging economic, social and environmental challenges.

The reminder of the paper is structured as follows. We first review previous studies and theory development related to VC and syndication and highlight the decision tree of capital investment. Four hypotheses to be tested on the basis of the Australian data are outlined as they relate to the link between successful exit and quality venture selection, continuing receival of VC funds, increasing size of VC funds and syndicated investment. The next section describes the nethodology used to analyse the two Australian hi-tech industries, namely information and communication technology (ICT) and biotechnology, medical and health (BMH). This is followed by presentation and discussion of the empirical findings. The concluding section summarises the results and oulines the new challendes for the VC industry as it adapts to environmental, social and governance (ESG) demands.

\section{Literature Review}

\subsection{Attractiveness of Venture Capital Funds}

Venture capital funds are invested in young and promising enterprises which often have little or no performance trackrecord and inadequate access to the resources available in the market. These companies have high risk of failure and high variability in performance (Tayebjee \& Bruno, 1984b; Ruhnka \& Young, 1987). Since, the market knows little about the prospect of such companies, the external investors are confronted with substantial 
informational asymmetry and adverse selection problems while investing in them. The VC funds and their managers, also known as venture capitalists, make a special contribution to the financial intermediation market by acting as an informed agent for investors with a better capability of screening the companies (Chan, 1983). Furthermore, it has been found that VC-backed companies achieve higher success rate compared to other new ventures (Davis \& Stetson, 1985). The VC-backed companies tend to outperform others in terms of profit, productivity, sales as well as research and development (Guo \& Jiang, 2013). Furthermore, initial public offerings backed by reputable VC firms are less likely to get delisted for performance compared to other new listings (Chou, Cheng, \& Chien, 2013). Therefore VC funds have been attractive not only to the large institutional investors willing to invest in promising technology start-ups, but also for retail investors.

Although VC as an investment model has been widely discussed (Tyebjee \& Bruno, 1984a; Sahlman, 1990; Bygrave \& Timmons, 1992; Fried \& Hisrich, 1994; Gompers \& Lerner, 2001), there has been insufficient effort to understand and appreciate its throng and vulnerabilities. Such an analysis is essential as the VC industry, along with other forms of financial intermediaries, can be exposed to susceptibilities and viability risk, such as during the global financial crisis (GFC). This research builds on the classic VC theory and provides a simple but insightful analysis of its investment model. It shows its benefits and that it is important for VC practitioners in the current financial industry's emerging culture not to neglect some of the fundamentals.

\subsection{Classic Venture Capital Theory}

The classic VC investment theory states that in order to minimise risk, the VC investment process occurs as a sequential path starting with deal orientation, screening and evaluation followed by structuring, investing and monitoring. Beside industry type, stage and location of the investee company, investment size and the VC firms' investment policy play an important role in the different stages of the decisions process (Tyebjee \& Bruno, 1984a; Ruhnka \& Yong, 1987; Fried \& Hisrich, 1994). Venture capital firms usually receive a number of business proposals from entrepreneurs. The deals are originated through cold callings, technology scanning and referrals, including a considerable number of referrals made by other venture capitalists looking for syndication (Tyebjee $\&$ Bruno, 1984b). In the investment screening and evaluation process, syndication and syndication networks play a significant role through sharing information about deals, knowledge of the ventures' industry and market (Lerner 1994; Stuart, Hong, \& Hybels, 1999).

Following the evaluation and selection of the deal, its structuring requires appropriate allocation of risk and control rights which usually entails the use of stage financing and convertible securities (Berglöf, 1994; Hellmann, 1998). Financing the ventures in stages becomes inevitable for managing risk and liquidity over time as well as for adding value in the post-investment phases (Gompers, 1995; Cornelli \& Yosha, 2003). Gompers (1995) points out that the most common practices in the VC industry include financing in stages, using convertible securities and forming investment syndications. While stage financing and use of convertible securities are fairly obvious practices in $\mathrm{VC}$ investment, syndication is not performed in all venture financing.

Post-investment monitoring and adding value are also common management practice in the VC industry with VC fund managers usually involved in the investee companies' management and board (Gorman \& Sahlman, 1989; Jääskeläinen, Maula, \& Seppä, 2006). It is nonetheless not straightforward to determine how this practice contributes individually to the ventures' development and success along with other measures, although their collective influence is obvious. Furthermore, the comparison between the market performance of VC-backed new ventures vis-à-vis the rest has received inadequate attention. This however can potentially highlight the strength of VC, especially in developing new ventures. As highlighted by Hsu (2006) and Alexy, Block, Sandner $\&$ Wal (2012), venture capital has the most significant contribution among other financial intermediaries in terms of shaping and developing new ventures.

\subsection{Venture Capital Investment Decision Flow}

Figure 1 depicts a simple decision tree to illustrate the theoretical VC process. In simple terms, VC investment is explained as a decision process where a $\mathrm{VC}$ firm considers investing in a new venture with the aim of achieving a rewarding exit. The high investment risk in new ventures is well recognised. Venture capital firms receive many business proposals from entrepreneurs seeking funds. They first take a venture into consideration based on their own expertise, industry preference, fund availability and investment policies.

Ventures go through development stages, including start-up, early or expansion stage. Further screening and evauation are carried out by the VC firm based on information available about its quality. The VC firm can thereafter consider the first round of investment in that venture. If the investment takes place, the venture capitalists become involved in the management and closely monitor the developments. This also gives the VC managers the opportunity to obtain further information about the venture's prospect and helps them evaluate 
whether further investment should be made. In the next stage, the venture capitalists decide whether to inject another round of funding or abandon the venture. This process can continue for several rounds (see Fig. 1) before an exit option is considered. The venture capitalists obtain their final return upon a successful exit.

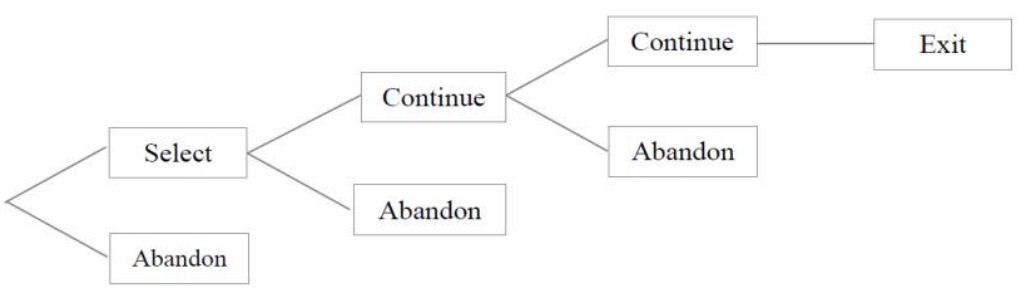

Figure 1. Venture capital investment decision flow

\subsection{Syndication Decision}

The decision to syndicate an investment fundamentally considers key issues in any VC investment process. There is an extensive literature available on syndication as well as its impact on the ventures' success which can therefore shed light on the core strengths of $\mathrm{VC}$ investment. Investment syndication in the venture capital market is fairly common with some regional variations. For example, almost one third of the European VC investments and around two thirds for the US venture investments are syndicated (Manigart et al., 2006; Jääskeläinen, 2012). Bygrave (1987) in his pioneering work on VC syndication argued that uncertainty associated with investment and need to access the specialised resources of other investors primarily drive syndication. The VC firms often look for peer endorsement and second opinion about a venture's quality. While a VC firm seeks a suitable co-investor and makes a proposal to syndicate, considering and accepting it by other experienced VC firms can be considered as a tangible endorsement of the quality of the venture (Lerner, 1994; Stuart et al., 1999; Casamatta \& Haritchabalet, 2007). Reduction of investment risk through screening and selection is therefore recognised as a key driver in the syndication decision (Lockett \& Wright, 2001; Brander et al., 2002; De Clercq \& Dimov, 2004; Hopp \& Rieder, 2011). Selecting a quality venture and taking up the investment opportunity before the competitors can be a vital source of portfolio success. If the VC firms are more certain about the ventures' quality they are less likely to seek any co-investors for further quality endorsement (Brander et al., 2002). Thus, the venture screening and evaluation process is largely similar whether it is done by an individual VC firm or a syndicate of VC firms.

During the post-investment monitoring, the venture capitalists not only provide funds to the portfolio companies but also supply nonfinancial resources, such as knowledge, expertise and market networks (Sapienza, 1992; Das, Jo, \& Kim, 2011). The VC syndicates similarly provide value-added services, while the syndicating VC firms can further pool financial and nonfinancial resources and enhance the ventures' performance (Lockett \& Wright, 2001; Ferrary, 2010; Hopp \& Rieder, 2011). Furthermore, the syndication activities take the VC firms beyond arm-length transactions to a network of relationships over time and space. This in turn provides the entrepreneurs with an access to venture capitalists' networks of professionals, such as lawyers, financial advisors and distributors, in the process of going public or obtaining a lucrative private divestment opportunity. A single venture investor in a company may not enjoy the options and opportunities created by a group of VC firms.

In the literature, the ventures' performance is usually presented with the successful exit option or the internal rate of return (IRR) and VC syndication generally views this positively (Jääskeläinen, 2012). Brander et al. (2002) investigated $584 \mathrm{VC}$ exits in the US and found that the syndicated ventures enjoy significantly higher return compared to the rest. Lehmann (2006) found that syndication in Germany has significant impact on shareholder value creation. Tian (2011) suggests that syndicates create both product market and financial market value for the ventures. Similarly, the performance of VC funds engaged in syndication can be measured with the fund return and successful exits. Using actual data and controlling for the known determinants of the venture capital investment performance, Hochberg et al. (2007) found that well-networked venture capitalists do better in the market than their peers. Reputation can enhance the network position of the VC firms (Gu \& Lu, 2014) and companies backed by reputable VC firms are more likely to exit successfully (Baum, Clabrese, \& Silverman, 2000; Abell \& Nisar, 2007; Nahata, 2008). 
Venture capital firms have been instrumental in enhancing innovation, facilitating market entry, professionalising the start-up companies and creating public companies (Kortum \& Lerner, 2000; Gompers \& Lerner, 2001; Hellmann \& Puri, 2002). The VC activities also stimulate other economic activities through employment creation, consumption enhancement as well as through knowledge transfer (Samila \& Sorensen, 2011; Deloitte Access Economics, 2013).

Since both individual VC firm or a syndicate of firms go through a selection and value creation process, syndication can act as an enhancing factor in that through further information and resource aggregation. Nonetheless, the VC firms investing alone can be equipped with sufficient information and resources for achieving success. It is also logical to expect that successful ventures, irrespective of the number of investors they have, would demonstrate certain patterns in their lifecycle. This is empirically investigated with the investment and exit history of Australian VC-backed companies over the period between 1984 and 2008.

\section{Hypotheses}

There is no one single way for a VC firm to invest and manage a portfolio companies nor is there a unique answer as to how a venture capitalist leads a venture to success. However, the drivers of success must lie within the uniqueness of $\mathrm{VC}$ as an investment model. The $\mathrm{VC}$ theory described above captures the fundamental structure of the $\mathrm{VC}$ investment process. It explains that the pre-investment screening and evaluation leading to the venture selection and then post-investment management and value creation are the two vital steps before a venture could attain a successful exit. In addition, at any stage the decision to invest in the venture could be made by one or more VC firms. For example, at the selection stage before the first VC financing round there could be two VC firms involved where one or both could be the lead VC firm/s in the syndicate. Similarly, a VC firm can invest alone in the first round and obtain one or more new investors in the following round, and so on. Once the investment is made, it is presumed that all VC investors join the founder managers in the management and value creation process.

We argue that, given the market deal flow, only good quality ventures are likely to obtain attention from venture capitalists with industry expertise and experience. Then through the initial selection process a venture receives the first round of VC investment. Concurrently good quality ventures must produce signals to the VC firms to attract investment. Such signals could be their commitment and ability to survive the market conditions since the time they were founded. These ventures are then likely to obtain VC finance and also likely to allow successful exit which leads to our first prediction - H1. Once the investment is made, the quality of the venture is further revealed to the $\mathrm{VC}$ investors. They then become involved with the founders in the management of the venture. If the venture can achieve requisite growth, it can retain the interest of the investors longer in the market and likely to be successful which leads to our second prediction - H2. It is then logical to argue that the amount of investment in any growing venture is likely to increase and allow successful exit which leads to our third prediction $-\mathrm{H} 3$.

Brander et al. (2002) argue that VC firms syndicate to obtain assistance either in the pre-investment venture selection or in the post-investment value creation. The selection can be facilitated by information aggregation in the venture section with other VC firms as well as a second opinion or endorsement from another VC firm. As already argued here, selection and value creation are the core activities of a VC firm whether it invests alone or in a syndicate. Syndication however can be driven by both selection and value creation motives (Hopp \& Reider, 2011). It could improve the venture selection as well as enhance value creation and we predict that syndication would increase the probability of a venture's success which leads to our fourth prediction - H4.

The four hypotheses to be empirically tested with Australian data are as follows:

H1: The ventures which enter the VC market with quality signals are the ones likely to obtain a successful exit option.

H2: The ventures which can survive longer in the market conditions and continue receiving VC funds are the ones likely to obtain a successful exit option.

H3: The ventures which obtain increasing VC funds over the rounds are the ones likely to obtain a successful exit option.

H4: The ventures which obtain syndicated investment from two or more VC firms are the ones likely to obtain a successful exit option.

\section{Methodology}

Based on the classic VC investment theory, the above four hypotheses are tested using an original regression 
model and a dataset that has not been previously analysed. The rationale and suitability of the chosen research method for the purpose of answering the questions surrounding syndication in VC investment are explained below.

\subsection{Regression Model and Variables}

In order to relate the ventures' lifecycle variables with their exit performance we use a probit regression model estimated with the standard maximum likelihood procedure which is a suitable way of dealing with a dichotomous dependent variable (Finney, 1971). Moreover, probabilities greater than 0.5 for dichotomous dependent, independent nd control variables can be used as a way to classify ventures into specific categories. For example, based on the dependent variable, ventures can be categorised as successful or failed. In this study the dependent, one of the independent and both control variables are dichotomous. The probit model can produce the best estimates of the regression coefficients in such a situation (Cameron \& Trivedi, 2005).

The dichotomous dependent variable in the probit model is 'Success'. Venture capitalists are more likely to take the best ventures to the public market not only for higher profit but also for increased reputation. Another successful and profitable exit option is divestment in the private market through mergers and acquisition or leveraged buyouts. We consider these exits as successful. On the other hand, failure includes going bankrupt or becoming defunct. The values for the 'Success' dependent variable are then: 1 if the venture exits through initial public offering or private sale, such as mergers and acquisition, and 0 otherwise. Hence, the model estimates the probability of a venture being successful given the other independent variables.

The first independent variable is 'Selection' and is aimed at testing the validity of the first hypothesis (H1) which relates to selection. It is measured as the duration in days between the company's founding date and the first VC investment date. It is logical to expect that the companies need a certain period of time to produce tangible signals for attracting $\mathrm{VC}$ investors and this requires them to survive the market conditions until then. We expect the ventures' survival duration before obtaining VC finance to be longer for a successful exit and the co-efficient in the probit model to be positive. Similarly, the ventures which can continue to survive the market conditions and produce signals to obtain subsequent rounds of VC investments, are the ones likely to succeed. This second independent variable is defined as 'Survival' and is measured in days as the duration between the first and last round of VC investments. We expect its co-efficient to also be positive. The ventures which are growing would require higher capital injection. The other non-performing ventures are likely to be abandoned. We define the third independent variable as 'Growth' and measure it as VC funds increase between the first and final round of investment prior to exit. It is logical to expect that the ventures receiving higher investments are likely to exit successfully and we expect this co-efficient to be positive too.

The last independent variable is 'Syndication' which we define as dichotomous with a value of 1 if the venture is syndicated at any stage and 0 otherwise. We argue that syndicates aggregate more information and resources in the venture evaluation and value creation process. Hence, syndication can increase the likelihood of the ventures' success and we expect the co-efficient to be positive.

Finally, we recognise that industry type, VC firm type, investment stage and country can also influence the performance. However in this study we analyse only early stage VC investments in ventures located in Australia, and hence we use only industry and VC firm type as control variables in the probit regression nodel. We treat both as dichotomous variables - equal to 1 if the venture industry is BMH and 0 if it is ICT, for industry type; and equal to 1 for independent $\mathrm{VC}$ and 0 for captive $\mathrm{VC}$ firms, for $\mathrm{VC}$ firm type. However, we do not expect any significant impact of industry and firm type differences on the dependent variable.

\subsection{Data Description}

The data and information used for this empirical investigation are from the VentureXpert dataset of Thomson Reuters (Venture Economics, 2009). This dataset provides detailed information on VC investment activities, including company name, fund and firm profiles, VC investment stage, dates, amount and exit mode. We investigate the exit history of Australian VC-backed companies from 1984 to 2008. This period represents the first 25 years of the industry's lifespan in Australia. The dataset also provides industry classification for all ventures. Of particular interest are the technology related ventures which are classified under the two broad industries, namely BMH and ICT.

As VC is associated with investment in early stage technology ventures, we investigate investment in the ICT and $\mathrm{BMH}$ sectors only in early and expansion stage. This separates the observations form private equity investment in later stages and non-technology ventures. Historically, the VC industry in Australia was born inside a public policy incubator in 1984 (Lerner \& Watson, 2008). The industry continued to rely heavily on 
support from various government programs and policies while the market force remained week (Lerner \& Watson, 2008). Since the late 1990s however the fund raising and investment activates started to trend upward. The dataset shows that $92 \%$ of the investment activities in the observed period took place between 1998 and 2008. Investment in technology ventures in particular increased from $41.67 \%$ in $1984-1997$ to $51.87 \%$ during 1998-2008 (refer to Table 1).

Table 1. Venture investments, Australia, 1984-2008

\begin{tabular}{|c|c|c|c|c|}
\hline \multirow[t]{2}{*}{ Industry } & \multicolumn{2}{|c|}{ Ventures (1984-1997) } & \multicolumn{2}{|c|}{ Ventures (1998-2008) } \\
\hline & Total & $\%$ & Total & $\%$ \\
\hline Information and communication technology (ICT) & 25 & 29.77 & 386 & 35.19 \\
\hline Biotechnology, medical and health $(\mathrm{BMH})$ & 10 & 11.90 & 183 & 16.68 \\
\hline Others & 49 & 58.33 & 528 & 48.13 \\
\hline Total & 84 & 100.00 & 1097 & 100.00 \\
\hline
\end{tabular}

Source of data: Venture Economics, 2009.

Overall 126 Australian VC firms invested in Australian technology ventures during this period which includes 263 ICT and $139 \mathrm{BMH}$ companies. Given the relatively small size and brief history of the Australian VC industry, it was possible to also analyse all exits. As the VentureXpert dataset provides investment details at the venture level, we have recorded the venture founding date, financing dates, investment amount, venture stage and industry classification until exit. Only the investments made in the early (seed and start-up) and expansion stage are considered as VC investments while the later stage and buyout transactions are excluded from this analysis.

Using the industry classification provided in the dataset, we analysed only the technology related ventures leaving out the other non-technology ventures. During the studied period, of all VC related investments $66.94 \%$ were active in BMH and $63.01 \%$ in ICT industry (refer to Table 2). Of the active investments, 54.55\% were syndicated in BMH and 61.54\% were syndicated in ICT industry. In the BHM sector, from the companies which reached the exit stage $\mathbf{I 8 . 1 8 \%}$ went public and $9.09 \%$ were acquired with the rest being not successful. From the syndicated investments in $\mathrm{BMH}, 30.30 \%$ went public and $6.06 \%$ were acquired through private arrangements. The share of acquisitions was higher in the ICT industry $-18.7 \%$ of all and $23.08 \%$ of the syndicated ventures, while the share of IPOs was smaller $-7.32 \%$ and 7.69 respectively. Interestingly, no syndicated investments went bankrupt in any of the two industries, although some were abandoned.

Table 2. Investment status and exit, VC investments in Australia, 1984-2008

\begin{tabular}{ccccc}
\hline Industry & \multicolumn{2}{c}{ Biotechnology, medical and health (BMH) } & \multicolumn{2}{c}{ Information and communication technology (ICT) } \\
\hline Status & All Ventures $(\%)$ & Syndicated Ventures $(\%)$ & All Ventures $(\%)$ & Syndicated Ventures $(\%)$ \\
\hline Active & 66.94 & 54.55 & 63.01 & 61.54 \\
Initial public offering (IPO) & 18.18 & 30.30 & 7.32 & 7.69 \\
Mergers \& Acquisition (M\&A) & 9.09 & 6.06 & 18.70 & 23.08 \\
Defunct & 4.96 & 9.09 & 8.94 & 7.69 \\
Bankrupt & 0.83 & NA & 2.03 & NA \\
\hline
\end{tabular}

Source of data: Venture Economics, 2009.

\section{Results and Analysis}

The regression outputs for the probit model were obtained using the Stata software package (Cameron \& Trivedi, 2010). As shown in Table 3, the regression results generally validate our predictions. We claim that the survival and duration analysis of a venture can capture its lifecycle and predict success. It is also logical to expect that syndication can improve the venture selection and value creation process and therefore enhance the chance of success. These results have several implications for the VC industry, especially in Australia. 
Table 3. The probit model of successful exit, VC investments in Australia, 1984-2008

\begin{tabular}{lll}
\hline Dependent Variable: Probability of Success & Coefficient & 'z' Value \\
\hline Independent variables & & \\
\hline Selection & 0.000312 & $1.91^{*}$ \\
Survival & 0.000737 & $1.70^{*}$ \\
Growth & 0.048816 & $1.95^{*}$ \\
Syndication & 1.295710 & $2.11^{* *}$ \\
\hline Control variables & & \\
\hline Industry & 0.170321 & 1.63 \\
VC Firm Type & 0.243551 & 2.81 \\
Constant & -2.007134 & -2.42 \\
\hline
\end{tabular}

Note. Number of observation: 61, Log Likelihood Ratio: 25.95, **Significant at 5\% level and *Significant at $10 \%$ level.

The first hypothesis examines the selection of a good quality venture which is the first step towards achieving a successful exit. As a standard practice, the VC firms evaluate all available information about the various ventures, their prospects and management team. At the same time, the entrepreneur managers need to produce credible signals to attract VC investors. The finding from our analysis suggests that in the Australian VC market the entrepreneurs require the venture to survive longer to prove the viability of the business and commitments from the funders. Hence, a longer duration of the time between the company's founding date and the first round of external VC investment is a suitable predictor of the venture quality and future success. The VC firms are supposed to be well equipped to screen technology start-up companies earlier before the competitors. Thereby better quality ventures are likely to obtain $\mathrm{VC}$ funds earlier than others in the market because of the competition among VC firms in the search for quality ventures. Nonetheless, a longer duration before selection may lead to investments in more mature stages which may reflect lack of proficiency in screening early stage ventures on the part of the $\mathrm{VC}$ industry as well as a low risk appetite of the $\mathrm{VC}$ investors leading to higher preference for later stage ventures. Our finding is consistent with Australia's VC industry's bias toward later stage ventures (Golis, 2010; Lerner \& Watson, 2008).

The validation of the second and third hypotheses implies that the VC firms continue to nurture potentially successful ventures until a suitable exit option is available and increase the investment amount to facilitate growth. However, holding a venture longer with increasing injection of funds could adversely affect the VC funds' annualised internal rate of return (IRR). The exit performance therefore must compensate for holding a venture longer in the VC firm's portfolio.

Finally, we validate the claim that investment syndication can strongly influence the probability of success. The regression results also indicate that the effect of syndication on the likelihood of success is more significant than the other variables. This is consistent with findings based on data from other parts of the world which indicate that syndication overall has a positive impact on the ventures' performance (e.g. Brander et al., 2002; Lehmann, 2006; Tian, 2011). The result however differs with Fleming (2004) who used 1992-2002 Australian data and found that syndication has a negative impact on the ventures' IRR. By comparison, our investigation covers a longer time period and captures market developments since the late 1990s with greater investment activates (as shown in Table 1).

\section{Discussion}

It is well recognised that $\mathrm{VC}$ has made significant contribution around the world to technological innovation and productivity as well as to the creation of successful and influential corporations. In this study we revisited the classic VC investment theory and model vis-à-vis co-investment behaviour and explored the main characteristic strength of the model. Two key broad elements of the $\mathrm{VC}$ model, namely pre-investment selection and post-investment value creation, contribute in particular to the ventures' success. Specialised knowledge of the venture industry as well as managerial expertise in enterprise development are required in addition to financial funds. In Australia however there has been little progress made in terms of generating VC fund managers with expertise in early stage technology ventures (Treasury \& DIISRTE, 2012). The result is reflected in the market preference for mature ventures. However, syndication can enhance the process of quality venture selection and value creation by pooling information and expertise from multiple $\mathrm{VC}$ firms.

Furthermore, the high risk environment of the VC industry has increasingly been exposed to a new wave of environmental, social and governance (ESG) risk which is bringing new opportunities to the innovative entrepreneurs (Teti, Dell'Acqua, \& Zocchi, 2012). The next generation of VC managers must address ESG risk 
and opportunities for a sustainable future. In response, a growing number of $\mathrm{VC}$ funds are now investing in new ventures engaged in clean technologies and innovative social businesses. Nevertheless any significant market development in this direction would require more new entrepreneurs venturing into these industries and more venture capitalists with relevant industry expertise. After all, availability of funds does not necessarily substitute the expertise of traditional venture capitalists.

The long-term viability of the $\mathrm{VC}$ industry requires producing and attracting more talents who will increasingly contribute to pre-investment venture selection and post-investment monitoring. However, the gap in expertise and resources can be addressed to some extent by resource-pooling through investment syndication. The commitment of the entrepreneurs and resilience of a venture's business model then not only help it to survive the market conditions, but also help it attract investment. Thus, the lifecycle analysis of the successful Australian enterprises reveals certain characteristics of the VC cycle in this country with wider implications for the industry participants and policy makers.

\section{Acknowledgement}

The second author acknowledges financial support from the Australian Research Council.

\section{References}

Abell, P., \& Nisar, T. M. (2007). Performance effects of venture capital firm networks. Management Decision, 45(5), 923-936. http://dx.doi.org/10.1108/00251740710753729

Alexy, O. T., Block, J. H., Sandner, P., \& Ter Wal, A. L. (2012). Social capital of venture capitalists and start-up funding. Small Business Economics, 39(4), 835-851. http://dx.doi.org/10.1007/s11187-011-9337-4

Baum, J. A., Calabrese, T., \& Silverman, B. S. (2000). Don't go it alone: Alliance network composition and startups' performance in Canadian biotechnology. Strategic Management Journal, 21(3), 267-294. http://dx.doi.org/10.1002/(SICI)1097-0266(200003)21:3\%3C267::AID-SMJ89\%3E3.0.CO;2-8

Berglöf, E. (1994). A control theory of venture capital finance. Journal of Law, Economics, and Organization, 10(2), 247-267.

Brander, J. A., Amit, R., \& Antweiler, W. (2002). Venture selection vs. the value-added hypothesis. Journal of Economics \& Management Strategy, 11(3), 423-452. http://dx.doi.org/10.1111/j.1430-9134.2002.00423.x

Bygrave, W. D. (1987). Syndicated investments by venture capital firms: A networking perspective. Journal of Business Venturing, 2(2), 139-154. http://dx.doi.org/10.1016/0883-9026(87)90004-8

Bygrave, W. D., \& Timmons J. A. (1992). Venture capital at the crossroads. Boston, MA: Harvard Business School Press.

Cameron, A. C., \& Trivedi, P. K. (2005). Microeconometrics: Methods and applications. Cambridge, UK: Cambridge University Press.

Cameron, A. C., \& Trivedi, P. K. (2010). Microeconometrics using stata: Revised edition. College Station, TA: Stata Press.

Casamatta, C., \& Haritchabalet, C. (2007). Experience, screening and syndication in venture capital investments. Journal of Financial Intermediation, 16(3), 368-398. http://dx.doi.org/10.1016/j.jfi.2007.03.003

Chahine, S., Arthurs, J. D., Filatotchev, I., \& Hoskisson, R. E. (2012). The effects of venture capital syndicate diversity on earnings management and performance of IPOs in the US and UK: An institutional perspective. Journal of Corporate Finance, 18(1), 179-192. http://dx.doi.org/10.1016/j.jcorpfin.2011.11.007

Chan, Y. S. (1983). On the positive role of financial intermediation in allocation of venture capital in a market with imperfect information. The Journal of Finance, 38(5), 1543-1568. http://dx.doi.org/10.1111/j.1540-6261.1983.tb03840.x

Chou, T. K., Cheng, J. C., \& Chien, C. C. (2013). How useful is venture capital prestige? Evidence from IPO survivability. Small Business Economics, 40(4), 843-863. http://dx.doi.org/10.1007/s11187-011-9389-5

Cochrane, J. H. (2005). The risk and return of venture capital. Journal of Financial Economics, 75(1), 3-52. http://dx.doi.org/10.1016/j.jfineco.2004.03.006

Cornelli, F., \& Yosha, O. (2003). Stage financing and the role of convertible securities. The Review of Economic Studies, 70(1), 1-32. http://dx.doi.org/10.1111/1467-937X.00235

Das, S. R., Jo, H., \& Kim, Y. (2011). Polishing diamonds in the rough: The sources of syndicated venture

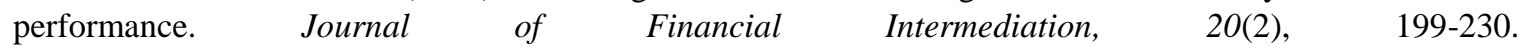


http://dx.doi.org/10.1016/j.jfi.2010.08.001

Davis, Jr, T. J., \& Stetson Jr, C. P. (1985). Creating successful venture-backed companies. Journal of Business Strategy, 5(3), 45-58. http://dx.doi.org/10.1108/eb039074

De Clercq, D., \& Dimov, D. (2004). Explaining venture capital firms' syndication behaviour: A longitudinal study. Venture Capital: An International Journal of Entrepreneurial Finance, 6(4), 243-256. http://dx.doi.org/10.1080/1369106042000277688

Deloitte Access Economics. (2013). Economic contribution of private equity in Australia: The Australian private equity and venture capital association limited. Retrieved from https://www.avcal.com.au/documents/item/530

Ferrary, M. (2010). Syndication of venture capital investment: The art of resource pooling. Entrepreneurship Theory and Practice, 34(5), 885-907. http://dx.doi.org/10.1111/j.1540-6520.2009.00356.x

Finney, D. J. (1971). Probit analysis (3rd ed.). New York: Cambridge University Press.

Fleming, G. (2004). Venture capital returns in Australia. Venture Capital, 6(1), 23-45. http://dx.doi.org/10.1080/1369106042000175573

Fried, V. H., \& Hisrich, R. D. (1994). Toward a model of venture capital investment decision making. Financial management, 23(3), 28-37. http://dx.doi.org/10.2307/3665619

Golis, C. (2010). Enterprise and venture capital: A business builders' and investors' handbook. Sydney, Australia: Allen and Unwin.

Gompers, P. A. (1995). Optimal investment, monitoring, and the staging of venture capital. The Journal of Finance, 50(5), 1461-1489. http://dx.doi.org/10.1111/j.1540-6261.1995.tb05185.x

Gompers, P., \& Lerner, J. (2001). The venture capital revolution. Journal of Economic Perspectives, 15(2), 145-168. http://dx.doi.org/10.1257/jep.15.2.145

Gorman, M., \& Sahlman, W. A. (1989). What do venture capitalists do? Journal of Business Venturing, 4(4), 231-248. http://dx.doi.org/10.1016/0883-9026(89)90014-1

$\mathrm{Gu}$, Q., \& Lu, X. (2014). Unraveling the mechanisms of reputation and alliance formation: A study of venture capital syndication in China. Strategic Management Journal, 35(5), 739-750. http://dx.doi.org/10.1002/smj.2117

Guo, D., \& Jiang, K. (2013). Venture capital investment and the performance of entrepreneurial firms: Evidence from China. Journal of Corporate Finance, 22, 375-395. http://dx.doi.org/10.1016/j.jcorpfin.2013.07.001

Hellmann, T. (1998). The allocation of control rights in venture capital contracts. The RAND Journal of Economics, 29(1), 57-76. http://dx.doi.org/10.2307/2555816

Hellmann, T. J., \& Puri, M. (2002). Venture capital and the professionalisation of start-up firms: empirical evidence. Journal of Finance, 57(1), 169-197. http://dx.doi.org/10.1111/1540-6261.00419

Hochberg, Y. V., Ljungqvist, A., \& Lu, Y. (2007). Whom you know matters: Venture capital networks and investment performance. The Journal of Finance, 62(1), 251-301. http://dx.doi.org/10.1111/j.1540-6261.2007.01207.x

Hopp, C., \& Lukas, C. (2014). A signalling perspective on partner selection in venture capital syndicates. Entrepreneurship Theory and Practice, 38(3), 635-670. http://dx.doi.org/10.1111/etap.12023

Hopp, C., \& Rieder, F. (2011). What drives venture capital syndication? Applied Economics, 43(23), 3089-3102. http://dx.doi.org/10.1080/00036840903427257

Hsu, D. H. (2006). Venture capitalists and cooperative start-up commercialization strategy. Management Science, 52(2), 204-219. http://dx.doi.org/10.1287/mnsc. 1050.0480

Jäskeläinen, M. (2012). Venture capital syndication: Synthesis and future directions. International Journal of Management Reviews, 14(4), 444-463. http://dx.doi.org/10.1111/j.1468-2370.2011.00325.x

Jääskeläinen, M., Maula, M., \& Seppä, T. (2006). Allocation of attention to portfolio companies and the performance of venture capital firms. Entrepreneurship Theory and Practice, 30(2), 185-206. http://dx.doi.org/10.1111/j.1540-6520.2006.00117.x

Kortum, S., \& Lerner, J. (2000). Assessing the contribution of venture capital to innovation. RAND Journal of Economics, 31(4), 674-692. http://dx.doi.org/10.2307/2696354 
Lehmann, E. E. (2006). Does venture capital syndication spur employment growth and shareholder value? Evidence from German IPO data. Small Business Economics, 26(5), 455-464. http://dx.doi.org/10.1007/s11187-005-5599-z

Lerner, J. (1994). The syndication of venture capital investments. Financial Management, 23(3), 16-27. http://dx.doi.org/10.2307/3665618

Lerner, J., \& Watson, B. (2008). The public venture capital challenge: The Australian case. Venture Capital, 10(1), 1-20. http://dx.doi.org/10.1080/13691060701605538

Lockett, A., \& Wright, M. (2001). The syndication of venture capital investments. Omega, 29(5), 375-390. http://dx.doi.org/10.1016/S0305-0483(01)00024-X

Manigart, S., Lockett, A., Meuleman, M., Wright, M., Landström, H., Bruining, H., ... \& Hommel, U. (2006). Venture capitalists' decision to syndicate. Entrepreneurship Theory and Practice, 30(2), 131-153. http://dx.doi.org/10.1111/j.1540-6520.2006.00115.x

Nahata, R. (2008). Venture capital reputation and investment performance. Journal of Financial Economics, 90(2), 127-151. http://dx.doi.org/10.1016/j.jfineco.2007.11.008

Repullo, R., \& Suarez, J. (2004). Venture capital finance: A security design approach. Review of Finance, 8(1), 75-108. http://dx.doi.org/10.1023/B:EUFI.0000022158.96140.f8

Ruhnka, J. C., \& Young, J. E. (1987). A venture capital model of the development process for new ventures. Journal of Business Venturing, 2(2), 167-184. http://dx.doi.org/10.1016/0883-9026(87)90006-1

Sahlman, W. A. (1990). The structure and governance of venture-capital organizations. Journal of Financial Economics, 27(2), 473-521. http://dx.doi.org/10.1016/0304-405X(90)90065-8

Samila, S., \& Sorenson, O. (2011). Venture capital, entrepreneurship, and economic growth. The Review of Economics and Statistics, 93(1), 338-349. http://dx.doi.org/10.1162/REST_a_00066

Sapienza, H. J. (1992). When do venture capitalists add value? Journal of Business Venturing, 7(1), 9-27. http://dx.doi.org/10.1016/0883-9026(92)90032-M

Stuart, T. E., Hoang, H., \& Hybels, R. C. (1999). Interorganizational endorsements and the performance of

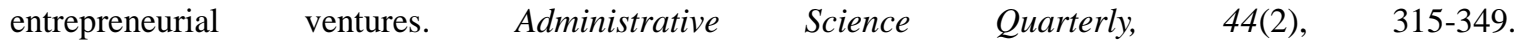
http://dx.doi.org/10.2307/2666998

Teti, E., Dell'Acqua, A., \& Zocchi, F. (2012). UN PRI and private equity returns: Empirical evidence from the US market. Investment Management and Financial Innovations, 9(3), 60-67.

Tian, X. (2011). The role of venture capital syndication in value creation for entrepreneurial firms. Review of Finance, 16(10), 245-283. http://dx.doi.org/10.1093/rof/rfr019

Treasury and Department of Industry, Innovation, Science, Research and Tertiary Education (DIISRTE). (2012). Review of venture capital and entrepreneurial skills: A report for the Australian Government. Final Report. Retrieved from http://www.avcal.com.au/documents/item/516

Tyebjee, T. T., \& Bruno, A. V. (1984a). A model of venture capitalist investment activity. Management Science, 30(9), 1051-1066. http://dx.doi.org/10.1287/mnsc.30.9.1051

Tyebjee, T. T., \& Bruno, A. V. (1984b). Venture capital: Investor and investee perspectives. Technovation, 2(3), 185-208. http://dx.doi.org/10.1016/0166-4972(84)90003-8

Tykvová, T. (2007). Who chooses whom? Syndication, skills and reputation. Review of Financial Economics, 16(1), 5-28. http://dx.doi.org/10.1016/j.rfe.2005.10.001

Venture Economics. (2009). Venture Xpert Database. Boston, MA: Thomson Reuters.

Wright, M., \& Lockett, A. (2003). The structure and management of alliances: Syndication in venture capital $\begin{array}{llll}\text { industry. Journal of } & \text { Management }\end{array}$ http://dx.doi.org/10.1046/j.1467-6486.2003.00412.x

\section{Copyrights}

Copyright for this article is retained by the author(s), with first publication rights granted to the journal.

This is an open-access article distributed under the terms and conditions of the Creative Commons Attribution license (http://creativecommons.org/licenses/by/3.0/). 